\title{
Improvement of Public Speaking Skill Through Ice Breaking Method Ira Arini
}

\author{
$1^{\text {st }}$ Ira Arini \\ STKIP Setiabudhi Rangkasbitung \\ Indonesia \\ ira.arini@gmail.com \\ $4^{\text {th }}$ Iman Sampurna \\ STKIP Setiabudhi Rangkasbitung \\ Indonesia \\ $7^{\text {th }}$ Yuyun Yuningsih \\ STKIP Setiabudhi Rangkasbitung \\ Indonesia
}

\author{
$2^{\text {nd }}$ Dede Kurnia Adiputra \\ STKIP Setiabudhi Rangkasbitung \\ Indonesia \\ echasetia14@gmail.com \\ $5^{\text {th }}$ Putri Yuniar Fatmawati \\ STKIP Setiabudhi Rangkasbitung \\ Indonesia \\ $8^{\text {th }}$ Habib Cahyono \\ STKIP Setiabudhi Rangkasbitung \\ Indonesia
}

\author{
$3^{\text {rd }}$ Ade Eka Anggraini \\ STKIP Setiabudhi Rangkasbitung \\ Indonesia \\ $6^{\text {th }}$ Ajeng Ginanjar \\ STKIP Setiabudhi Rangkasbitung \\ Indonesia
}

\begin{abstract}
The purpose of this study is to improve public speaking skills through ice breaking methods for students of Penjaskes at STKIP Setiabudhi Rangkasbitung. This research method uses two cycles of action research methods. The population in this study amounted to 300 students and the sample in this study used a purposive sampling method totaling 50 students. The time of the study was carried out for 6 months from February 2019 to July 2019. The steps of the research carried out were compiling the planning, acting, observing, and reflecting. The results of the study for 2 cycles showed that the Public Speaking Skill for students of Penjaskes at STKIP Setiabudhi Rangkasbitung increased by using the ice breaking method by 9.6 points. This is evident from the results of the measurement of indicators of public speaking skills in cycle 1 with an average of 65.6 and cycle 2 with an average of 79.2. Thus it can be concluded that the ice breaking method in the Curriculum and Learning courses can improve the public speaking skills of students of the Physical Education Study Program at STKIP Setiabudhi Rangkasbitung.
\end{abstract}

Keywords-Public speaking skills, ice breaking, curriculum, learning

\section{INTRODUCTION}

Public speaking skill is one of the skills that must be possessed by an educator in supporting his profession. Talks that are smooth, clear, systematic, easy to understand, comfortable voice volume, expressions and body language that are used in harmony with what is conveyed are important things that need to be considered by an educator. Educators who have good public speaking skills will look stunning and attract the attention of students so that the message delivered will be more effective.

As a higher education institution that provide prospective educators and education personnel, the skill of public speaking needs to be inserted in the hidden curriculum.

The students of Physical and Health Education study program at STKIP Setiabudhi Rangkasbitung, the majority of whom tend to have physical kinesthetic intelligence, have not been maximal in mastering public speaking skills. Through the ice breaking technique that is inserted in the Curriculum and Learning courses, it can improve the public speaking skills of students of the Penjaskes study program at STKIP Setiabudhi Rangkasbitung. Ice breaking is one of the activities carried out to practice concentration in the class, provide a sense of comfort and reduce the saturation of the Physical Education students who tend to have physical kinesthetic intelligence. In addition, ice breaking can also provide opportunities for students to get to know each other better and break the awkward atmosphere in class during lectures.

Based on preliminary observations, student behavior tends to prefer learning in a practical field rather than learning in a theoretical classroom. So that, this study is entitled Improving Public Speaking Skill by using the Ice Breaking Technique. The purpose of this research is to improve the skill of public speaking by using ice breaking techniques.

Ice-Breakers are a part of creative thinking, strategic thinking, positive thinking, problem solving and learning strategies, not only in business oeganizations but also for students of all age groups [1]. The reason is classroom Ice-Breaker activities help to develop various soft skills such as interpersonal skill, communication skills that include written, verbal and non-verbal and team building skills [2]. Ice-Breaker activities also help in creating a bond between students and teachers. Classroom Ice- 
Breaker activity on new class or school can help newcomers [3].

In using Ice-Breaker we need a strategy. The strategies of using Ice-Breakers as follow [4]:

- Objectives and Execution: Before teachers and students start any Ice-Breaker activities, they need to be aware of two things: what they are going to achieve and how they are going to achieve it.

- Group Size: Teachers also need to choose activities based on the size of the group. If the teachers and students have a large number of people, they can have them interact with a series of leading questions. By giving them leading questions and having them talk to one another, the teacher forces them to talk about things other than small talk, which will let them find some common ground. Small groups can have their Ice-Breaker with the teacher rather than having them intearct independently. The teachers could just follow the questions stated previously, but with they asking rather than having them ask one another.

- Appropriatness:Teachers and students should choose an Ice-Breaker strategy based on how appropriate it is for the students. The Ice-Breakers that will be used in the classroom also be consideration for the teacher to get the student's attention. The teacher should make sure that IceBreaker chosen is actually connected to the intended purposes of the Ice-Breaker. This is very important because not all kind of Ice-Breakers work for intended end.

- Considering the problems and explanations above, this study focuses in researching the effectiveness of Ice-Breaker activity to improve students' Speaking skill and to find out the students' perceptions towards the effectiveness of IceBreaker activity to improve their Speaking skill.

\section{METHOD}

This research is a classroom action research, which is a study that emphasizes activities (actions) that try an idea into practice or real situations on a micro scale that are expected to be able to improve the quality of teaching and learning process [5].

The hypothesis in this study is: "through the application of ice breaking in the Curriculum and Learning lectures will improve the public speaking skill of the 4th semester students of the Physical and Health Education Study Program STKIP Setiabudhi Rangkasbitung academic year 2018/2019".

The study was conducted at STKIP Setiabudhi Rangkasbitung in the academic year 2019/2019 for 6 (six) months. The data source is classical learning activities, with research participants in semester 4 of Physical and Health Education study programs. Research collaborators are fellow lecturers. Research instruments in the form of interview guidelines, check lists of public speaking skills with a Likert scale, and observation guidelines. In general, action research can be described as follows [6]:

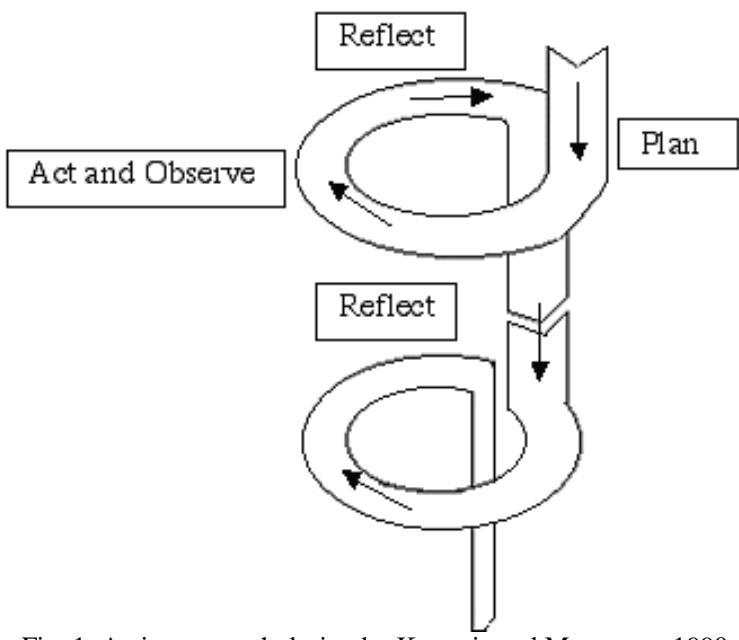

Fig. 1. Action research design by Kemmis and Mctaggart, 1990

\section{A. Planning}

At the beginning of planning, discussions were held with the Lembaga Penelitian dan Pengabdian Masyarakat (LPPM) in the context of conducting action research to be carried out. Based on preliminary data that has been obtained, the researcher tries to formulate the problem as follows:
- Improve the learning techniques provided. If you usually use lecture techniques, then the technique that will be used in learning is the technique of giving ice breaking.

- The material given in this study is the material contained in the syllabus of the curriculum and learning courses namely "Motivation and Curriculum"

TABLE I. ACTION IMPLEMENTATION PLAN

\begin{tabular}{|c|c|c|c|}
\hline No & Learning curse & Technique & Time \\
\hline 1 & Motivation & Ice breaking & April 3 and 10, 2019 \\
\hline 2 & Curriculum & Ice breaking & May 1 and 8, 2019 \\
\hline
\end{tabular}




\section{B. Actions}

Based on the previous planning, action will be taken in cycle I, namely:

- Introduction of students about the activities to be carried out

- Dividing student groups into group presentations and having to insert ice breaking techniques into their presentations.

- Give assignments to other students who do not advance presentations to become observers and take note of the small things that still lack the group in achieving public speaking skills

C. Observations

Observations are made to see whether the actions in the cycle are in accordance with what is planned. In addition, enthusiasm and participation of students during the learning process were also seen. Observations were made with the help of collaborators, use an observation sheet. Form observation sheets that use relatively detailed categories. The observation sheet is adapted where the tallies mark becomes the check mark $(\sqrt{ })$ that showsthe presence or absence of appropriate action.

\section{Reflection}

At the end of each observation a meeting is held with the collaborator to hold a reflection actions taken during the service process. When reflection is shown supporting data in the form of observations and information from collaborators in the field. Reflection is carried out with the aim to carry out the planning of the next action.

\section{RESULT}

This class action research was conducted in 2 (two) cycles. Each cycle consists of 2 (two) meetings. Following is a description of the implementation of class actions.

\section{A. Cycle Planning I}

\section{Reconnaissance}

The basis for conducting this action research is the preliminary data found in the field regarding the lack of public speaking skills in STKIP Penjaskes study program students Setiabudhi Rangkasbitung. Problems arise in class mastery when presenting student groups on Curriculum and Learning courses for semester 4 (four). This is evidenced by the quiz answers given to students after exposure to material by unclear groups. In other words, students' understanding of the material presented by the group was also lacking. In fact, the papers compiled by the student groups are clear and detailed. One reason for this is that there was a lack of clarity about the group's presentation at the presentation due to a lack of public speaking skills. The results of a checklist of students' public speaking abilities are only 59.2 points. Therefore, the ability of public speaking in students needs to be improved.

\section{Planning for action}

Referring to the results of initial data collection, action will be taken to solve the learning problem. The planning stages in the first cycle are as follows:

- Holding meetings with P3M and Head of Study Program related to the problems found in the initial data collection stage. The researcher also gave a presentation on the solution of the problem found in the form of action research to improve students' public speaking ability.

- Actions that will be implemented refer to the theory of Groover

- Classes to be used are Curriculum and Learning classes in semester 4 (four) with a total of 50 students.

- The action to be taken consists of 2 (two) meetings for each 1 (one) subject. Provision of action in the first cycle in the form of the use of ice breaking techniques. The time used is the course schedule for Curriculum and Learning courses with a time allocation of $2 \times 50$ minutes for each meeting.

- After the second meeting, the researcher will conduct a reflection based on the results of cycle I.

\section{Actions and Observations}

Based on planning, the actions taken refer to the theory. At the first meeting of the first cycle, the researcher presented preliminary information about the activities to be carried out. The subject of this cycle $I$ is Motivation as outlined in the syllabus of the Curriculum and Learning course. After that, the researcher identified the problem explicitly by assigning a group of material presentations using ice breaking. Researchers invite students to actively express their opinions in group discussions. But in this first cycle, the responses given by students tend to be passive. Students did not give the slightest response regarding the material and ice breaking revealed. At this first meeting, it was agreed by group I to present the material while the other groups became observers. At this first meeting, researchers did not give concrete assignments to students, so at the next meeting the students tended to be passive again.

At the second meeting, groups of students who are presentations are welcome to come to the front of the class. Another group becomes the participant in the class discussion. After the group discussion activities are finished, all class members are invited to review the material that has been presented by the group.

Based on observations at the second meeting, the group of students who presented the material looked more prepared than the previous group. This can be seen from the review of more active classroom material compared to the first meeting. However, there are still some students who have not been active in the course of the presentation because they are still shy to argue. The group of students presenting ahead using the ice breaking technique was only representative, not all groups used the technique. As a result, the observation checklist cannot be generalized to the ability of public speaking per person but rather as a group. The results of a checklist of students' public speaking abilities to 65.6 increased 6.4 points from preaction. However, this increase has not been significant and has not yet reached the research objectives so reflection is needed to review the overall actions taken.

\section{Reflection}

Every time an observation is finished, the next step to do is to reflect [7]. This step is carried out by researchers with related parties in the institution to see the advantages 
and disadvantages in cycle I. Based on the results of observations in cycle $\mathrm{I}$, the following is the result of reflection:

- At the stage of group division, students who have more public speaking skills than other students tend to be in the same group.

- Student groups that lack public speaking skills provide less direction to the discussion participants so the discussion goes unfocused.

- The material load carried out is not maximally reached. Students tend to be passive in the course of discussion and the group presenting the material also has not been able to master the discussion. In one group, only one student was dominant in presenting material with ice breaking techniques.

B. Cycle II

\section{Planning}

Planning in cycle II is carried out based on the reflection of cycle I, namely:

- Students who have better public speaking skills than other students are distributed to the group fairly.

- Students who have less public speaking ability, provide direction to the discussion participants in the course of the discussion so hopefully the discussion will run more focused.

- Before the group discussion goes on, a re-clarification regarding the obligation to use ice breaking techniques in the course of the material discussion by each student who presents.

- Researchers as lecturers are able to be firm in managing the class so that students are more focused on the material presented by the group.

2. The act of observation

At this second cycle meeting, the researcher again revealed the initial description of the material that would be presented by the group. The material in this second cycle is the curriculum contained in the curriculum and learning syllabus. In this process, researchers also provide the opportunity to ask students about the course of discussion. Not much different from the first cycle, the discussion in the second cycle only added the results of reflection in the first cycle.

At the first meeting, the researcher observed the course of discussion regarding the curriculum material. Every student who explains in a group discussion is required to insert the ice breaking technique as well as possible.
Researchers assess using a checklist of students' public speaking abilities, one of which is by looking at the focus and mastery of the class [8].

At the second meeting, groups of students who will make presentations are welcome with the same provisions that every student who explains the material is required to provide ice breaking techniques. The result, discussion participants were more enthusiastic in the course of the discussion and of course the focus and mastery of the class of students whose presentations were increased

The results of the checklist of students' public speaking ability to 79.2 increased by 9.6 points from cycle I. The increase has reached the research objectives but there are still some that need to be improved so that reflection on this cycle needs to be done.

\section{Reflection}

Every time an observation is finished, the next step to do is to reflect. This step was carried out by researchers with related parties in the institution to see the advantages and disadvantages in cycle II. based on the results of observations in cycle II, the following is the result of reflection:

- The ability of public speaking students has been improved, but can not be said to be optimal. This can be proven by the results of the public speaking ability checklist which shows an average number of 79.2.

- There are still some students who have not mastered the class, but have tried ice breaking techniques in the presentation process of presenting material in class.

- The activeness and focus of students in the classroom has increased. When compared to cycle I, in cycle II there was an increase.

Based on the results of the public speaking checklist, it can be seen in the results of the frequency distribution table using the following steps:

- Determine the range of student scores, and use the lowest score as the lower limit of the first class.

- Determine the number of Sturge formula classes, i.e. $\mathrm{k}$ $=1+3.3 \log \mathrm{n}$, or specify the desired class interval, and determine the number of classes using range.

- Create class intervals and calculate falling observation frequencies for each class using tally.

- Number of frequencies from each class [8]. The frequency is then expressed as a percentage of the total frequency, so the table becomes a relative frequency table.

TABLE II. RELATIVE FREQUENCY TABLE PUBLIC SPEAKING ABILITY SCORE CYCLE I
\begin{tabular}{|c|c|c|}
\hline Class Interval & Frequence & Relative Frequence \\
\hline $51-55$ & 2 & $4 \%$ \\
\hline $56-60$ & 8 & $16 \%$ \\
\hline $61-65$ & 18 & $36 \%$ \\
\hline $66-70$ & 13 & $26 \%$ \\
\hline $71-75$ & 7 & $14 \%$ \\
\hline $76-80$ & 2 & $4 \%$ \\
\hline Total & 50 & 100 \\
\hline
\end{tabular}


TABLE III. .RELATIVE FREQUENCY TABLE PUBLIC SPEAKING ABILITY SCORE CYCLE II

\begin{tabular}{|c|c|c|}
\hline Class Interval & Frequence & Relative Frequence \\
\hline $61-65$ & 2 & $10 \%$ \\
\hline $66-70$ & 5 & $26 \%$ \\
\hline $71-75$ & 13 & $30 \%$ \\
\hline $76-80$ & 15 & $16 \%$ \\
\hline $81-85$ & 8 & $14 \%$ \\
\hline $86-90$ & 7 & 100 \\
\hline Total & 50 & 4 \\
\hline
\end{tabular}

In cycle I, the lowest score is 51 and the highest is 80 , while the maximum expected score is 100 . The average score in the cycle is 65.6. The formula for calculating the average attitude scale score uses the formula Total Score of students divided by the number of students. While in cycle II, the lowest score is 61 and the highest is 90, while the maximum expected score is 100 . The average score in cycle II is 79.2. This means an increase of 9.6 points from cycle I. The increase in this score can be determined by using the formula to find the percentage increase, namely:

$\mathrm{P}=\frac{\text { Post Rate-Base Rate }}{\text { Base } \text { Rate }}$ 100\%
Based on these data, can be analyzed that the average score of students' public speaking abilities in each cycle for the Likert scale has reached the expected score. This means that for the Likert scale shows relatively high effectiveness and there has been an increase of each cycle. This also means that in each cycle there has been a significant increase. Overall, the application of ice breaking techniques in improving students' public speaking abilities is quite effective. This is evidenced by the average score that has increased in each cycle, the results of the observation sheet and the results of interviews with students. Comparison of the average score of each cycle can be seen in the graph below.

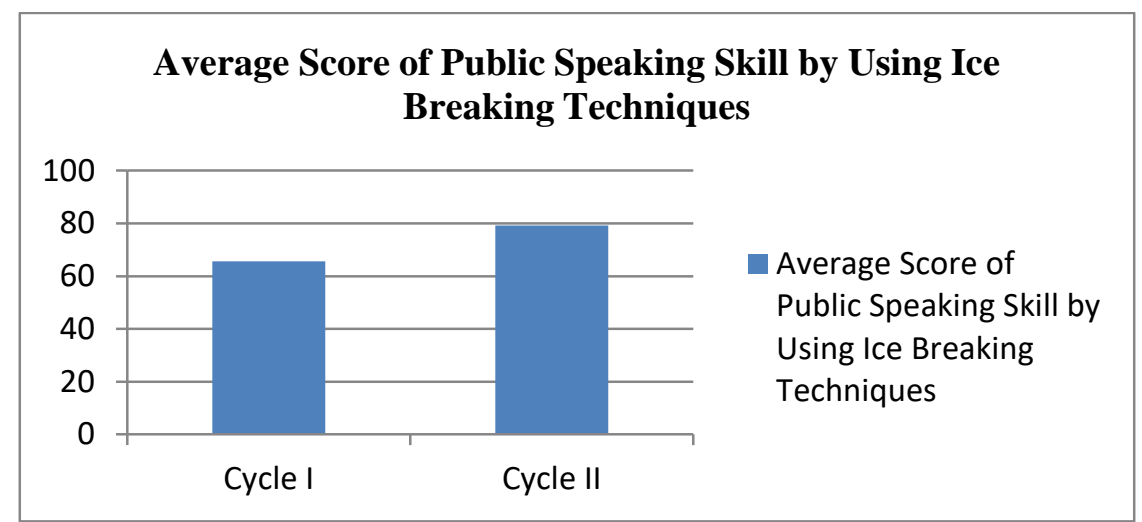

Fig. 2. Average Score of Public Speaking Skill by Using Ice Breaking Techniques

IV. DISCUSSION AND CONCLUSION

The research which was conducted in 2 (two) cycles using the Kemmis and Taggart models concluded that with the application of ice breaking techniques in the Curriculum and Learning subjects of the 4th semester students of Penjaskes Study Program STKIP Setiabudhi Rangkasbitung there was a significant increase. But in the process there are many things that need to be considered in relation to students' public speaking skills. Students need more time and practice to really master the class during the discussion so that the discussion participants are more focused in the learning process. The ice breaking technique should be done with a script so that the preparation and seriousness of students become better and can improve the public speaking skill in front of the class.

\section{REFERENCES}

[1] Dixon, J., Crooks, H., \& Henry, K. 2008. Breaking the Ice: Supporting Collaboration and Development of Community. Canadian Journal of Learning and Technology.
[2] Forbes-Greene, Sue. 1982. The Encyclopedia of Icebreakers: Structured Activities That Warm-Up, Motivate, Challenge, Acquaint and Energize. Retrieved from: http//www.paperbackswap.com/Encyclo pedia-IcebreakersStructured-ActivitiesWarm/book/0898890055.htm

[3] Pitts, Errol. 2010. Ice-Breaker in the Classroom. http://www.ehow.com/info 8153338 ice-breeaker-as-warming up.html

[4] Groover, Sam. 2005. Ice Breaker Strategies. Retrieved from: $\mathrm{http} / /$ www.ehow breakersstrategies.html\#ixzzls6ESFmMLIce

[5] Arikunto,Suharsimi.2011.Prosedur PenelitianSuatu PendekatanPraktek.Jakarta:PT.RinekaCipta.

[6] Sugiyono.2011.MetodePenelitianKuantitatif,Kualitatif dan R\&D. Bandung:Alfabeta.

[7] Mulyasa, E. 2009. Menjadi Guru Profesional. Band- ung: Remaja Rosdakarya

[8] Pugach,M.C.2006.BecauseTeachingMatters.USA Willey/Jossey-BassEducation.Thornbury, S. 2006. How to teach speaking. Harlow, England: Longman

[9] Sugiyono.2014.StatistikauntukPenelitian.Bandung: Alfabeta. 